taken at this observatory under his direction and that of his son, are now being used to determine the distances of stars by a method due to Prof. W. S. Adams, one of the foreign members of the observatory. The measurements are being made by Mr. D. L. Edwards and Mr. W. B. Rimmer. The Department of Scientific and Industrial Research has made a grant to the latter for the purpose of carrying out a portion of this research while attached to the observatory. The equipment and opportunities here for both education and research in the physics and chemistry of celestial bodies are as full and free as could be desired by the most progressive student or investigator. The endowment of two or three research scholarships tenable at this observatory would be the best service that could be rendered to astronomy; and would certainly result in notable increase of our knowledge of the heavens.

It is remarkable that in the United States funds are provided for observatories and astronomical work, by both university institutions and private benefactions, on a scale far beyond anything available in this country. We once led in astronomy, but America now surpasses us both as regards great observatories and remarkable achievements. Whatever funds are required for buildings, equipment, and workers are readily forthcoming, whereas here benefactions for astronomical work are extremely rare. The Mount Wilson Observatory, where the best astronomical work in the world is now being carried on under the direction of Dr. G. E. Hale, one of our foreign members, cost more than a quarter of a million pounds, and has an annual income exceeding 40,00ol. It possesses a roo-inch telescope, upon which more than roo,oool. has been expended, and it was in connexion with this instrument that nearly two years ago the remarkable achievement was accomplished of measuring the diameters of certain stars, among them the star Antares, which proves to have a diameter of 400 million miles. - The Yerkes Observatory, Lick Observatory, Harvard College Observatory, and Lowell Observatory are other examples of great astronomical institutions in the United States which we both admire and envy. The difficulty there is not to obtain funds for astronomical work, but men who will devote their lives to it: here we have plenty of men eager to take up astronomical research but no means to provide them with the necessary instruments and modest salaries to maintain them.

The Norman Lockyer Observatory is the only institution of its kind in this country, and it owes its existence to the generosity of a few people who believe that to place here a temple devoted to the increase of knowledge of the heavens is to provide a mansion in the skies. The county, the nation, and the whole world of science, owe a deep debt of gratitude to the founder and to his supporters, for this fire building reaching out high unto the stars to question them and understand the messages they send us in their beams.
For the means to continue and extend the work so nobly instituted and profitably begun, we appeal to all who are interested in the pursuit of knowledge for its own sake or because of its uplifting influence upon the spirit of man. .In faith and hope we ask that this memorable occasion shall mark the beginning of a new and enlarged stage in the history of this observatory, and that the future will see upon this site a centre of modern astronomical research which will maintain the prestige of British science throughout the world and be a worthy memorial to the renowned astronomer who built here this tower from which the heavens can be scanned for intellectual expansion and the enlightenment which the spirit of man is ever seeking as to his destiny.

Col. J. E. H. Balfour, High Sheriff and Lord of the Manor of Sidmouth, expressed on behalf of the county appreciation of Sir Norman's association with. Devon and the neighbourhood of Sidmouth. While Sidmouth was famed for its natural advantages of climate and scenery it was little thought that these advantages would be turned to such wonderful and useful purposes. He was glad to know that the confidence felt in the suitability of the site for the observatory had been amply justified, and he deemed it an honour to Sidmouth to possess such an observatory. $\mathrm{He}$ expressed the wish that the observatory would have a great future in the advancement of science and knowledge that it deserved.

The Rev. J. S. Cornish recalled that in his memory the grounds of the observatory were formerly one of the wildest and least useful parts of Salcombe Regis. He little thought it possible that from such an expanse of waste would arise an institution that had already become known throughout the scientific world. $\mathrm{He}$ referred to the stone of the old sun-worshippers, which still stands near the observatory land where now the modern astronomer reads the truth of the stars with his magnificent telescopes. $\mathrm{He}$ hoped that the observatory would become increasingly famous throughout the world, as was the heart's desire of its founder, Sir Norman Lockyer.

Lady Lockyer heartily thanked those who had assembled that day for the unveiling ceremony. Sir Norman looked forward to the observatory being a place where research students could carry out investigations in any branch of spectroscopic research. The provision of a library was essential to house the large collection of books. This would cost about $2000 \mathrm{l}$. and they had not that amount of money to spend on it. She hoped a much greater interest would be taken in the work of the observatory, and that the expansion of its activities would not suffer from lack of support. Lady Lockyer expressed the gratitude of Sir Norman's family that his portrait was erected in the observatory which he founded and directed, and which now, by the wish of all the members, bears his name.

\title{
Pioneer Work in Submarine Cable Telegraphy.
}

THE jubilee celebrations of the Eastern Associated Telegraph Companies are so nearly contemporaneous as to seem to be almost part of the commemoration of the foundation of the Institution of Electrical Engineers, which antedated that of the Company by only a few months. These celebrations carry with them a warning not to lose our sense of historic proportion: they remind us that before a Society of Telegraph Engineers could be established, telegraph engineering had already been well founded, and that the great submarine cable company which now for fifty years has served the Empire and the whole world with such conspicuous ability and commercial success could scarcely have been the concept of the earlier pioneer days. Only when the art of submarine telegraphy had been amply assured of success could so great a commercial undertaking as that which the Eastern Telegraph Company is now celebrating be initiated.

The following notes on the pioneer work of the cable engineers and others have been drawn freely from the discourse which Sir Charles Bright delivered at the Electrical Engineers' commemoration.

Perhaps it is a little far-fetched to treat quite 
seriously the earliest suggestion that electric signals might be sent under the sea. Yet it is worth while to note that so early as I8II an effort was made to discover a suitable insulating covering for a submarine wire and that the material used was indiarubber. The decisive factor whereby submarine telegraphy became a practical proposition was, however, contributed by Dr. Werner Siemens in $\mathbf{1} 847$ when he laid a telegraph cable in Berlin with wires insulated by gutta-percha. Faraday, as Sir Charles Bright reminds us, was also at the same time directing attention to the insulating properties of this new material. Gutta-percha has never from that day to this had a serious rival for insulation of deep-sea cables.

Not that the pioneers had waited for it! Previously, in June 1845 , the brothers Brett, although only small shopkeepers, in the true spirit of the old merchant venturers applied for government sanction to the provision of telegraphic communication between England and France. When the concession came in 1849 , gutta-percha had come into its own and most of the cable laid was of copper wire with a half-inch coating of gutta-percha. The need for a special " shore-end " was recognised even then; but it is puzzling to know why a different insulation should have been adopted. Yet we read that "the shore-ends for about 2 miles from each terminus consisted of a No. I6 BWG. conductor covered with cotton soaked in indiarubber solution, the whole being encased in a very thick lead tube." It is scarcely surprising that it failed, but not before, by transmission of a few signals, it had demonstrated the practicability of ocean telegraphy. A " mad freak," a " gigantic swindle," but, like many another failure, a signpost to success. The next year a new concession was secured and the Submarine Telegraph Company was formed, but it was only floated on the capital of a railway engineer (Thomas $R$. Crampton) and his friends. The resulting cable, not completed until the end of I85I, marked another development of the engineer's art in cable-making. Küper, a colliery engineer, suggested sheathing the insulated wire with iron wires like a colliery pit rope ; and so was reached the essential, and till now the final, form of the successful and trustworthy submarine cable.

Perhaps one day some one will write a work on "Government versus Enterprise" in the hope that responsible public servants may be taught by their predecessors' failures. In $185^{\circ}$ the Bretts again found that, "although sensible of their" perseverance in bringing the submarine telegraph about," the Government could do nothing to help, and so- " landing rights " not having yet been invented-the Bretts proceeded on their own responsibility to span the
Irish Channel. Ultimately success was achieved in I853, with Charles Tilston Bright (aged 21) in command as engineer to the Magnetic Telegraph Company.

These efforts, however, although they had demonstrated the practicability of submarine telegraphy, had not finished the work of the pioneer-the great unfathomed depths of ocean had yet to be spanned. To put a cable miles deep on the bed of the Atlantic would be impossible, it was said, even if signals could be passed through the enormous length of 2000 miles. Of course pioneers are never very anxious to do anything but the impossible; so J. W. Brett, Cyrus Field (a wealthy American business man who incidentally had discovered, or perhaps invented, "landing rights" for Newfoundland) and Charles Bright (as engineer) projected and with other venturers formed the Atlantic Telegraph Company and secured the required capital in a few days. This was of course only the beginning of the pioneer engineers' work. The British and the United States Governments encouraged and helped the scheme with men - of - war, and at last on August 5, I 858 , the shore-end having been duly landed at Newfoundland, the telegraph had bridged the ocean; and the Times could say" since the discovery of Columbus nothing has been done in any degree comparable to the vast enlargement which has thus been given to the sphere of human activity." Unfortunately, although the practicability of the scheme had been amply demonstrated and the engineering success was unquestionable, after about two months' work the communication failed-the conductivity of the cable was too low and the power applied to it was too high.

Then followed cables to the east-to Malta, Alexandria and India via the Persian Gulf, and it was not until 1865 that any further effort to lay a cable across the Atlantic was projected. In the meantime, Lord Kelvin had perfected his wonderful mirror apparatus, the progenitor of the syphon recorder ; closer knowledge of the actual requirements had been secured and improvements in methods of manufacture developed. Also the paying-out and picking-up gear had been largely developed by Henry Clifford, and Brunel's great ship the Great Eastern was available to take the large core cable that Bright had succeeded in securing. By the end of I866 there were two cables working across the Atlantic and the pioneers had about finished their part of the business. The next was routine-and skill combined with knowledge. Other cables followed, east and west; and then in 1872 commenced the great commercial achievements under Sir John Pender, which the Eastern Telegraph Companies are celebrating, after fifty years, with such justifiable pride.

\section{International Chemistry.}

THE International Union of Pure and Applied Chemistry held a successful annual meeting in Lyons on June 27-July 2. This was the third annual meeting and a good deal of time was, as on the former occasions, devoted to the details of organisation and the business of getting such an international body well established. Prof. Moureu has been president for three years and has had a difficult task in framing a policy for the score of nations who are now represented in the Union and in guiding them into harmony in these troublous times. $\mathrm{He}$ has achieved his desire, and the Union seems likely to continue for many years and to have an increasing importance. It is intended in the future to pay more attention to the purely scientific side of the subject and to attempt some discussions which will be of permanent value.
The Lyons meeting was well attended, about a hundred and twenty delegates taking part, among whom may be mentioned Messrs. Swarts and Timmermans (Belgium), Billmann (Denmark), Mourelo (Spain), Parsons, Bartow, and Washburn (United States), Grignard, Kestner, Marie, Moureu, and Perrin (France), Pope, Lowry, Hewitt, and Mond (Great Britain), Nasini and Paterno (Italy), Bodtker (Norway), Cohen, Kruyt, and Verkade (Holland), and Votǒek (Czecho-Slovakia). Lyons is well provided with suitable buildings for the various meetings and social functions and there are many objects of interest in the vicinity. The commissions on nomenclature, publications, standards, food analysis, industrial hygiene, and international patents continued their work and presented interim reports. To carry out the recommendations of these commissions 